\title{
Trajectories of violence: the border experiences of peruvian women between Tacna (Peru) and Arica (Chile)*
}

\author{
Trayectorias de la violencia: Las experiencias fronterizas de \\ mujeres peruanas entre Tacna (Perú) \\ y Arica (Chile)
}

Trajetórias de violência: as experiências fronteiriças de mulheres peruanas entre Tacna (Peru) e Arica (Chile)

Recebido em 16-08-2019

Modificado em 06-11-2019

Aceito para publicação em 21-11-2019

\section{Menara Lube Guizardi}

ORCID: 0000-0003-2670-9360

Doutora em Antropologia Social. Pesquisadora Pós-doutoral do Consejo Nacional de Investigaciones Científicas y Técnicas (Argentina) e pesquisadora associada da Universidad de Tarapacá (Chile). E-mail: menaraguizardi@yahoo.com.br

\section{Eleonora López Contreras}

ORCID: 0000-0003-0820-7391

Mestre em Sociologia. Doutoranda do Programa de Pós-graduação em Sociologia da Pontificia Universidad Católica de Chile. E-mail: eleonoralopezcontreras@gmail.com

\section{Felipe Valdebenito}

ORCID: 0000-0002-3250-8808

Graduado em Antropologia. Doutorando do Programa de Pós-graduação em antropologia da Universidad Católica del Norte (Chile) em cotutela com a Universidade de Sorbonne (Francia). E-mail: valdeb.felipe@gmail.com

\section{Esteban Nazal}

ORCID: 0000-0001-7172-7221

Mestre em sociologia. Professor do Departamento de Antropologia da Universidad Alberto Hurtado (Chile). Email: enazalmoreno@gmail.com

\footnotetext{
* The authors thank the Chilean National Commission of Scientific and Technological Research which funded the study that gave rise to this paper through Project FONDECYT 11121177: "Gender conflict, labour insertion and migratory itineraries of Peruvian women in Chile: a comparative analysis between the regions of AricaParinacota, Tarapacá and Valparaiso".
} 


\begin{abstract}
The article discusses the strategies articulated by Peruvian women in the border area between Chile and Peru to confront the historical legitimations of gender violence in this territory. In Peru, their trajectories are marked by violations, labor exploitation, kidnapping and slave labor. In Chile, other violence and discrimination (labor, documentary, sexist aggressions) persist, being supported in a discourse on the ethnic-national inferiority of Peruvians. Thus, there is a tension between social legitimacy and legal illegality, and between agency and subordination as far as gender violence is concerned. Supported by ethnographic data, we will define this tension as a process that (re) inscribes, in the vital trajectories of women, disparate forms of marginalization and border crossing.
\end{abstract}

Keywords: Gender, violence, female migration, Chile-Peru border.

\title{
Introduction
}

Since the 90s, the concern with international migration in Chile has acquired important dimensions, inspiring a prodigious academic production on the topic (Martínez, 2003:1; Núñez; Hoper, 2005:291; Schiappacasse, 2008:23; Stefoni, 2005:283-284). In 2011, when we began our studies about Peruvian migrants in the country, we carried out a state-of-the-art review of the scientific works published from the 80 s onwards. After compiling 76 publications we discovered that most of the socio-anthropological studies regarding international migration in Chile had only been published after the year 2000.

Most of these works repeatedly stated that Latin American migration to the country was irrelevant until the late 1990s. They also assumed that the re-democratization of the Chilean State, along with the cycle of economic growth fostered by this political transformation, turned the country into a priority destination for Latin American migrants (Araujo; Legua; Ossandón, 2002:8; Jensen, 2009:106; Poblete, 2006:184). In these studies, this "new" migration was usually described as originating in the bordering Andean countries (mainly from Peru $)^{1}$, as feminized ${ }^{2}$, and as destined almost exclusively to the center of the country (namely the national capital, Santiago). Among the 76 works reviewed, only 4 were focused on regions other than Santiago. Despite the above, the research results were presented

\footnotetext{
${ }^{1}$ In Chile, Peruvians have been the predominant national migrant group since 2002, currently accounting for $31.7 \%$ of registered migration (Rojas; Silva, 2016:14).

2 This feminization is, in fact, a sustained tendency: according to the National Socioeconomic Characterization Survey of Chile (Casen, 2013:7), between 2009 and 2013, the composition of the international female migrant population in the country rose from $51.5 \%$ to $55.1 \%$.
} 
as representative of migration "in Chile" (Guizardi; Garcés, 2014:231). Far from harmless, this semantic practice constituted a particular "methodological nationalism" that overdimensioned the role of the national capital in shaping social phenomena all over the country. A sort of "methodological Santiaguism" (Grimson; Guizardi, 2015:18).

At the same time, we observed a repeated focus on the feminine dimension of the phenomenon. Most of the work dealt with the Peruvian women who worked in domestic services in Santiago, portraying them as "the migrant women in Chile". This construction of a "priority subject of study" overshadowed the presence of migrant women of other nationalities, and the employment of migrant woman in general in other labor market niches. In addition, these studies made little mention about the presence of Peruvian women in the North of the country: in the border areas between Chile and Peru.

All these generalizations seemed odd to us, due to their incoherence with the daily experience of our research team members, who used to live in the North of Chile, where the presence of Peruvian and Bolivian migrants was both a historical and an everyday fact. Asking ourselves whether this Peruvian female migration really was a novelty in these Chilean territories so far from Santiago, we consulted new sources of information. Data from Chilean censuses and historiographical research confirmed that our suspicions were justified. They showed that Peruvians had been circulating, working, living and constituting an important percentage of the total population in the North of the country since the occupation of these territories by Chile, after the War of the Pacific (1879-1883) (Tapia, 2012:181).

These findings inspired the proposal of a research project that was then carried out between 2012 and 2015. The objective was to develop in depth ethnographic fieldwork following Peruvian migrant women in Arica, a northern Chilean city in the borders with Peru.

The results obtained exposed that the migratory profiles and social experiences of Peruvian women in Arica constituted a "border exceptionality": a particular female migration reality, dramatically characterized by social inequality and gender violence.

In the Peruvian women's life stories these violent excesses that differentiated the border area from the other cities of the study were deeply connected to constitutive moments of their life. In their memories, violence crossed the boundaries between here and there, between public and private, between allies and enemies. They were narrated by them as a transversal experience, experienced on both sides of the border. The latter brought our attention to the main topic of the present article: the processes that (re)produce the configurations of gender violence in the Chilean-Peruvian border area. 
To contextualize this debate, in the second section of the text we will characterize methodology of the study. In the third, we discuss the historical conformation of the patterns of gender abuse and violence on the Northern border of Chile. In the fourth section, we will theoretically discuss the relationship between patriarchy, Nation-state and gender-based violence in border areas. In the fifth section, we will draw up a migratory profile of Peruvian women in Arica based on quantitative data. We will also synthesize the socio-economic vulnerabilities faced by them in Peru and in Chile. The sixth section will analyze the qualitative information of the study, focusing on the reports of violence experienced by women in their families of origin in Peru. Finally, we will return to the theoretical reflections to redefine the violence lived by Peruvian women as a unequal forms of marginalization and border crossing.

\section{Methodology}

The study was developed through a mixed qualitative and quantitative methodological approach, articulated through the conjunction of the Extended Case Method (ECM) and Multisited Ethnography (ME). The Extended Case Method advocates historicizing and extrapolating ethnography to macro-social dimensions through the emphasis on disruptive interactions (the "social situations") and the use of quantitative data (Gluckman, 2006). Of Marxist inspiration, the ECM understands ethnography as praxis. Multisited Ethnography employs strategies of fieldwork mobility allowing researchers to subvert the categorical isomorphism between space and culture that cements the praxis of classical Malinowski ethnographic techniques (Marcus, 1995).

Between 2012 and 2013, we carried out ethnography on various spaces through which Peruvian women used to circulate in Arica: residences, hostels, shantytowns, Catholic Church welfare facilities, work and leisure environments, State offices, public health posts, and public schools. We also conducted 87 in-depth interviews. Among them, 32 are life-story interviews carried out with Peruvian women. The other 55 are semi-structured interviews developed with: male Peruvian migrants (10); female Bolivian who lived in shantytown neighborhoods with Peruvian woman (6); community leaders of the migrant shantytown neighborhoods (3); NGO staff and officials from public health and educational centers (21); Peruvian women imprisoned at Arica's Acha Prison (15). We also recorded about 250 ethnographic photographs and developed a systematic ethnographical diary for the whole period of team fieldwork. 
Between 2013 and 2014, we conducted a survey on 400 Peruvian female migrants (100 in each city). The survey complemented the qualitative results from the first year.

It contained 106 questions divided into eleven areas of inquiry: 1) Socio-demographic information; 2) Migratory displacement and itineraries; 3) Access to formal education; 4) Labor occupation; 4) Civil status; 5) Residential situation; 6) Documental Paperwork situation; 7) Maternity, children and family; 8) Remittances; 9) Gender relations; 10) Experiences of violence and 11) Reasons to migrate. Between 2014 and 2015, we digitized and systematized the survey data. Finally, we contrasted and analyzed all the data.

The data derived from this survey will be synthetized in the third section of this article. However, some preliminary methodological clarifications regarding this information must be made. The data that resulted from our survey cannot be extrapolated as a totalizing representation of the Peruvian migrant women's subgroup, since it derives from a nonprobabilistic and segmented sample (that included only women of an economically active age, between 15 and 65 years old $)^{3}$. Attentive to these aspects, we will triangulate the quantitative data contrasting it with the qualitative information collected through the ethnography and the in-depth interviews. If we entitled this section appealing to the metaphor of "drawing profiles", it is precisely to draw attention to the fact that these profiles result from an analytically selective process that, in its course, selects the elements that are made visible, and those that will be (at least momentarily) put aside. Assuming this selectiveness as a strategy, we will synthesize only the information that facilitates the interpretation of the qualitative data that will be detailed in the subsequent section. For the time being we will focus only on three aspects of the Peruvian women's "profile": their migratory trajectories, their family responsibilities, and their increasingly precarious labor together with their experiences of gender violence.

\section{Historical configurations}

Arica is the most northern Chilean city. With some 190,000 inhabitants, it is located on the Pacific coast and is the capital of the Chilean region of Arica y Parinacota, which borders Peru to the North and Bolivia to the Northeast (Vicuña et al. 2015:38). To the South, it borders with the Chilean region of Tarapacá, which in turn is followed (further South) by

\footnotetext{
${ }^{3}$ In our sample, $19 \%$ of the surveyed women were between 46 and 64 years old; $55 \%$ between 25 and 45 years, and $26 \%$ between 15 and 25 years.
} 
Antofagasta. These three Chilean regions constitute "the Great North of Chile" and are in the Atacama Desert.

Peruvian women in Arica have bi or multi-national circulatory experiences. They are involved in commerce, agriculture and domestic or care services between this Chilean city and the city of Tacna, some 52 kilometers away. The latter is the capital of the homologous department of Tacna and the nearest Peruvian urban settlement, with more than 300,000 inhabitants (Podestá, 2011:127). These cities have had a long lasting historical relationship (Rosenblitt, 2013:47-81): Arica served as a port to Tacna from the sixteenth century until they were separated with the division of Chile and Peru in 1929, after 46 years of violent litigation derived from the War of the Pacific (1879-1883) (Valdebenito; Guizardi, 2014:288). Currently, these cities catalyze much of the trade and human routes that intersect the Andean Tri-border-Area - between Chile, Peru and Bolivia -, playing a prominent role in the activities between these countries (Guizardi et al. 2014:168) ${ }^{4}$.

The Atacama people of the altiplano have a historically intense human and commercial mobility (Almihat-Szary, 2007). This crosses the orographic platforms that make up the territory from the Pacific coast to the Andean mountain peaks inland (Dillehay; Núñez, 1988; Tung, 2008); and in turn from what is currently called the "Andean Region of Bolivia" (where the cities of La Paz, Oruro and Potosí are located). From the sixteen century onwards, a busy commercial route was established between the Pacific coast, Arica and Ilo, and Potosí (Sempat, 1995:110), and to other cities located in the present day Peruvian highlands (e.g. Arequipa and Cuzco). These routes carried silver and precious metals for export through the port, allowing an exchange of food and supplies that kept the productive cycle in the mines going (Larson 1995:26; Stern 1995:77). Small-scale commercial activities were carried out by native women, who coordinated both the urban sale and the transit of products (Mangan, 2005:134-160). Therefore, ancestral patterns of women's mobility connecting the highland and coastal territories have long being identified in this territory.

This interconnection, however, was violently impacted by the conformation of national borders in the second half of the nineteenth century, especially after the Pacific War. The conflict, in which Chile confronted a Peruvian and Bolivian alliance, was motivated by disputes over the territories of mineral exploitation (rich in saltpeter and guano) in the Atacama Desert (Vitale, 2011:387), which were located in the departments of Tarapacá

\footnotetext{
${ }^{4}$ The Chilean Investigation Police (PDI) estimates some 6 million human beings cross annually between the Chilean border control of Chacalluta (in Arica) and the Peruvian one of Santa Rosa (in Tacna) (Pérez et al. 2015:52).
} 
(formerly Peruvian) and Antofagasta (formerly Bolivian). Chile ended the conflict "victorious", incorporating both departments into its geography but the country's limits with Bolivia and Peru were only established, respectively, in 1904 and in 1929.

The Chilean victory endorsed the ideology of an alleged racial difference between Chileans, on the one hand, and Peruvians and Bolivians, on the other (Beckman, 2009); associating the latter with an Indian identity understood as synonymous of barbarism, paganism and a lack of civilization (Mcevoy, 2011:15). The war also institutionalized patterns of gender violence linked to the militarization and masculinization that prevailed in the formation of borders between the three countries. Peruvian and Bolivian women (especially the indigenous) were systematically raped by the Chilean army throughout the conflict (Sater, 2007:92), and in the decades after its end. Women were fundamental to the Peruvian (Sater, 2007:77-78), Chilean (Larraín, 2000), and Bolivian armies (Sater, 2007:75) and to their militaries' campaigns. But their importance has been erased from the official historiography in the three countries. The war confirmed, especially in Chile, a representation of the national identity that reaffirms the masculine prominence as stated in military narratives. Furthermore, these gender violence practices became naturalized in the social imaginary in these areas: at present, women in the territories adjacent to the Andean Tri-border-area have fewer rights and suffer more violence, especially if they are indigenous.

Since the 1990s, the national and patriarchal imaginaries, which are constitutive of these three countries, have become more acute in the Chilean territories of the Atacama; mainly due to the intensification of Bolivian and Peruvian migration (Guizardi; Garcés, 2012). In the regions of Tarapacá, Arica y Parinacota and Antofagasta, migrants constituted $7.4 \%, 5.8 \%$ and $4.6 \%$ of the total population in 2015 , the highest percentages in the country (Rojas; Silva, 2016:12-13).

Even though this Peruvian and Bolivian migratory influx is feminized in almost all Chilean regions, the country's Northern territories have seen a greater increase in the proportion of women of these nationalities (Tapia; Ramos, 2013). This feminized migration is strongly conditioned by the mobilization of social networks linked to families in the country of origin. However, community ties reproduce patterns of gender inequality, fostering insecure and informal female labor, not to mention the emotional burden migrant women carry in relation to the care work inside the families. Thus, historical forms of mistreatment and female subordination are reproduced, legitimizing abuse and violence on a variety of scales. 


\section{Theoretical debates}

The debate on gender-based violence and its relationship with the patriarchy in the formation of Nation-states (and their borders) involves discussions that could hardly be summarized in a single article. Accordingly, our debate in this section will focus on the specific aspects of this relationship that structure our analytical perspective: namely, the linkage between gender-based violence and the dialectical dimension of patriarchy in border contexts (as an expression of the universalist values of the nation, and, simultaneously, as a particularized or regionalized social configuration). This linkage is one of the current configurations of the phenomena defined by Bourdieu as the "masculine domination", insofar it institutionalizes a "social order dominated by the masculine principle" (Bourdieu, 1998:17). This order is erected through the division of an archetypal image that projects the masculine as active, and the feminine as passive, "and that principle creates, organizes, expresses and directs the desire, the masculine desire as desire for possession, as domination" (Bourdieu, 1998:19).

In border areas, patriarchal mandates usually materialize through social practices that accentuate the distortions, exclusions and violence perpetrated against female elements (Monárrez; Tabuenca, 2013:8-9; Pickering, 2011:109-110; Segato, 2013:27-29). This has the effect of endorsing the hegemony of the local subgroups that regionally incarnate the role of "dominators" that the national social orders legitimize more broadly. To explain this statement reliably, it is necessary to approach it from two analytical axes.

The first refers to the ontologically dialectical role carried out by the cross-border areas regarding the particularization and diversification of identity ascriptions. Although a Euclidean conception of frontiers - inspired by a geographic fiction of sharp separation of the territories on both sides of the dividing line between nations - predominated in the social sciences for most of the $20^{\text {th }}$ century, the research developed in the last thirty years gives a much more complex vision of these areas. Thanks to these works, regions located at the confluence of two or more national spaces emerged as central areas for research (Perkmann; Sum, 2002). These zones have been discussed as scenarios of multi-scale phenomena (Sum, 2003) that challenge the founding ideologies of the Nation-state: the ethnic, phenotypic and cultural separation between the "ones" and the "others", and the spatially demarcated inscription of peoples and goods that supposedly belong to the nation (Kearney, 1991). Attentive to dialectics of border territories - between mobility and restriction, legality and illegality, uprootedness and belonging - Anglo-Saxon anthropologists have begun to theorize 
frontier spaces as constitutive of the tension between subject, history and culture since the $90 \mathrm{~s}$ (Grimson, 2003:15). Borders would thus be territories that are pluralistically contradictory, where Nation-states act structurally, while subjects also act by re-signifying and renegotiating the State's pretension to impose its categorical hierarchies (Brenna, 2011:12).

Anthropologists working on South American frontiers have introduced important nuances to these debates. In the framework of these discussions, Grimson (2000:28) pointed out that the porosity of borders:

[...] does not necessarily imply a modification of national identity classifications or self-classifications. Rather, it is on the existence of the frontier that a social system of exchanges is organized between groups considered to be distinct.

The fact that people cross frontiers does not mean that the borders disappear (Cardin, 2012). The juridical, political, economic and identity asymmetries between the neighboring nations, accelerated by globalization, would provoke the emergence of social practices that seek to benefit from these differences and liminalities between lawful and unlawful (Grimson, 2003). Border residents strategically use territorial circularity to reap benefits and to achieve their interests.

The second analytical axis is linked to the structuring character of gender conflicts in the relationship between identities and Nation-states in border areas. Gender is, in feminist theoretical terms, the cultural construction of the biological difference between the masculine and the feminine (Lamas, 1999:147). It is structured through a conflictive field: activating processes of dominance that affect both women and men, generating symbolic disputes that give form and content to the differences, inclusions and exclusions (Mills, 2003:42): a dialectical interplay between identities that is ontologically relational (Butler, 2011:39). As a social phenomenon, gender derives from a long-lasting social process, whereby male preeminence is established as an inequality of power: endorsing forms of differential control over "material and symbolic resources" (Lamas, 1999:150), and reproducing the sub-alternization of the female element (Monárrez; Tabuenca, 2013:8-9).

At this point, it is useful to follow Spivak's (1998) critical turn on Gramsci's arguments (Monárrez; Tabuenca, 2013) to assume that the transversality of the subalternization of women of different societies reflects the degree of legitimacy that the masculine domain constitutes in the most diverse areas. This domain ranges from the "private" to the "public" and supports the constitution of the identity principles that separate "We" from the "Others". These aspects are deeply constitutive of the Nation-state political structure. Returning to our 
first analytical axis, in contemporary societies, it is impossible to attend to Gramsci's indication of overcoming the tendency to see the subgroups that compose each social block as homogeneous, without understanding the founding role of gender as a factor of differentiation (Spivak, 1998). Consequently, it is not possible to advance to a de-homogenizing vision of the social groups in conflict for power -being the conflict established in economic, symbolic or identity terms- without incorporating a critical gender perspective.

As Dore (2000:9) discusses, the formation of Latin American Nation-states after the independence wars of the nineteenth century operated by reproducing (if not aggravating) the patriarchal, racial and caste system that was settled by colonialism. But, according to Segato (2003) gender-based inequalities of power originate in periods prior to the colonial era: they could be considered as an ontogenetic form of the constitution of human societies. Polemicizing Levi-Strauss's classical work on the structural function of kinship in human societies, Segato stresses that the departure point of cultures (if such a thing could really be traced, she adds) would be gender violence, insofar that the constitutive content of gender asymmetries is openly seen in the founding role of patriarchal violence as an elemental structure of cultures. This inference confers on patriarchy a definition that articulates (dialectically, as we understand it), the "particular" to the "universal".

In particular terms, patriarchy would be ${ }^{5}$ :

The name given to the order of status in the case of gender is a structure of relations between hierarchically ordered positions that has consequences at the observable and ethnographable levels, but it should not be confused with this factual level, nor are its consequences linear, causally determined or always predictable (Segato 2003:14).

But this does not dissolve its universalizing dimension, according to which it is understood as:

\begin{abstract}
Belonging to the symbolic stratum and, in psychoanalytical language, as the unconscious structure that drives the affections and distributes values among the characters of the social scene. The position of the patriarch is, therefore, a position in the symbolic field, which transposes into important variables in the course of social interactions. For this reason, patriarchy is both a norm and a project of selfreproduction and, as such, its plan emerges from a scrutiny, from a delayed ethnographic 'listening' sensitive to the power relations and its, sometimes immensely subtle, discursive expression (Segato, 2003:14).
\end{abstract}

Due to this complex particular-universalizing articulation of patriarchy, gender violence plays a central role "in the reproduction of the symbolic economy of power whose brand is gender [...]. It is a necessary act in the regular cycles of that power restoration" (Segato,

\footnotetext{
${ }^{5}$ Segato's texts reproduced in this section were translated by us from the original in Spanish.
} 
2003:13). Regarding this appreciation, we would like to highlight two elements that are essential for the present study.

On the one hand, we emphasize that the contradiction of patriarchy has a close parallel with the first two analytical axes that we synthesize in this section. The way national identities will be dialectically constituted on the frontier, breaking and reproducing the conformations of the national, engenders the reproduction of this dialectic between particularity and universality of gender violence that Segato links to the elementary structures of cultures. Borders are not, therefore, only areas that condense the construction of identities, conflicts and contacts between social groups belonging to one or another Nation-state: they also condense the structuring violence and contradictions of patriarchy ${ }^{6}$.

On the other hand, in the case of Latin American cross-border women, this condensation of factors is simultaneously linked to large macro-social and global phenomena that pushed them into migration, impacting gender relations. By articulating families, groups and organized communities across different national territories, migrant women act by globalizing their localities and reinventing child-rearing processes, as well as the family care system (Hondagneu-Sotelo; Ávila, 1997). All of this is configured even more intensely in border territories. The role of women in family mobility implies, simultaneously, that they will assume the driving role of an economic activity that will impact on the way families, marital relationships and the social tasks attributed to grandparents, uncles/aunts, and friends are formed (Bryceson; Vuorela, 2002).

In addition, the socio-economic insertion of the migrant exposes women to an intensification of the intersectionality of elements of social marginalization, which are also linked to their ethnic, class, and age affiliation (Crenshaw, 1991:1244). This intersectionality of exclusionary factors experienced by migrant women (in border areas and elsewhere), defines their spaces, rights and possibilities of social incorporation. But it does so by combining two simultaneous border experiences: that of belonging to a "gender otherness", and the other of living and literally challenging the frontiers of Nation-states.

Due to this complex incarnation of patriarchal contradictions in border areas, and the combined overlapping of exclusionary factors (chained to macro and micro-social, local and global processes), gender violence must be read in these territories as linked to a broader framework of domain and subalternization. However, none of the above implies that women

\footnotetext{
${ }^{6}$ In empirical terms, this consideration has been widely verified by studies carried out on the US-Mexico border (Monárrez; Tabuenca, 2013; Segato, 2013), but it can be said that the issue has received less attention on the South American borders.
} 
will not have a particular agency, with political dimensions, in the resistance of different scales to this violence. Therefore, following the analysis of Hydén, the present article situates its effort in the overcoming of the dichotomies between "victimization" and "agency" among battered women:

\begin{abstract}
The feminist political stance on 'agency' foregrounded female solidarity and shifted the position of the battered woman from that of a woman struggling alone with her batterer to a larger political confrontation with patriarchy. However, feminist theory to date has mainly focused on the pragmatics of intervention and on the position of women as unambiguous victims. Battered women's ways of opposing and resisting violence are still underemphasized, and ultimately insufficiently examined in feminist discourses of violence in close relationships (Hydén, 2005:140).
\end{abstract}

\title{
Migrants profiles
}

\section{Migratory Trajectories}

Most of the women we surveyed in Arica came from three Peruvian departments: Tacna (19\%), Puno (12\%) and Lima (12\%) (the first two are located in Southern Peruvian territories). The remaining $67 \%$ came from 39 different districts. Tacna was the last city of residence in Peru for $56 \%$ of them (regardless of whether they were born there or not), while $17 \%$ had migrated from Lima. Around $37 \%$ of the women surveyed in Arica had migrated from other Peruvian districts to Tacna before coming to the Chilean side of the border.

Although $75 \%$ of the respondents claimed to live in an urban context before migrating to Chile, $48 \%$ stated that their father had been born in a rural context, and $49 \%$ said that their mother had been too. In total, 103 different districts in Peru were mentioned as hometowns to the parents. In $22 \%$ of the cases, the relatives migrated together in Peru from the countryside to the city before the birth of the respondent. This data yields three interesting conclusions. 1) Although most women come from three specific districts, their families come from a multiplicity of localities, and so there is a strong family history of internal mobility in Peru. 2) However, families moved predominantly between rural localities. 3) Therefore, the women surveyed are often the first urban generations of their family. Qualitative interviews showed that a rural origin in Peru had exposed these women to precarious situations in terms of housing conditions (drinking water, electricity, basic sanitation) and access to citizens' rights (e.g. getting birth certificates and identity documents for themselves and their children, or 
accessing public health services). Despite the above, on average they had more years of formal education than Chilean national rates ${ }^{7}$.

The intense family patterns of migration had a huge impact on the life experience of these women when they were growing up. Although 37\% said that they had lived in only one Peruvian town before migrating to Chile, $29 \%$ declared having lived in two cities, $20 \%$ in three, and $14 \%$ in more than four. Overall, $63 \%$ of the respondents had had previous migratory experiences in Peru. However, only $7 \%$ had any previous international migratory experiences (3\% to Ecuador, $2 \%$ to Bolivia and $1 \%$ to Argentina). But their experience in Chile is not always restricted to their migration to Arica: $20 \%$ had migrated to one or more Chilean cities previously (among them, the most mentioned are Santiago, Antofagasta and Iquique). When asked about the length of their migratory experience, 33\% declared to have been living in Chile for over 11 years, while $24 \%$ had been in the country between 6 and 10 years, and $31 \%$ between 1 and 5 years (only 12\% had migrated in the year in which the survey was conducted).

When asked to indicate the main reason for their migration to Chile, $47 \%$ cited the lack of economic opportunities in Peru, while $11 \%$ indicated the lack of professional opportunities, and 9\% sought adventure. Around $22 \%$ stated reasons related to family matters $^{8}$, and $10 \%$ indicated that they had reasons of a different nature (which could refer to illicit activities, very usual among transborder inhabitants). This data shows that, contrary to what is generally postulated in studies on female migration, the principal push factor for these women is not family. Although their migration effectively ends up fulfilling a central role in the social reproduction of their primary (and sometimes also extensive) family nuclei, women migrate justly trying to find opportunities in the productive sector (and adventures), which will allow them to resize the rigidity of gender roles.

The latter does not mean that their family life or responsibilities are not important. When questioned about why they chose Chile and not another country, $49 \%$ mentioned the spatial proximity to their residences in Peru (suggesting the possibility of coming and going to see their families with ease), and $15 \%$ mentioned having family networks in this country. In

\footnotetext{
${ }^{7}$ Among the respondents, $99 \%$ reported that they had had access to formal education, and $98 \%$ stated they were able to read and write. Around $12 \%$ of the women had finished primary school, and $54 \%$ had completed high school. On the other hand, $17 \%$ had high-school technical studies, and $13 \%$ had college studies. In addition, $92 \%$ of the migrants carried out their studies in Peru (therefore, it would be inaccurate to suppose that they are taking over the public education system in Chile).

${ }^{8}$ Among them, 3\% wanted to be closer to their husbands; $9 \%$ sought better opportunities for their children, $6 \%$ migrated because of family contacts in Chile and $4 \%$ because they had relatives in the country.
} 
addition, $57 \%$ mentioned being the breadwinner of the household (only 12\% say that this function is carried out by their male partner).

Regarding the marital status of the respondents, $48 \%$ mentioned being single, $5 \%$ were separated (without having been legally divorced), and 3\% were widowed. Finally, $44 \%$ had a partner. Of these, $24 \%$ were married and $20 \%$ cohabited. In the interviews, many women told us that their decision to migrate was linked to the desire to break up a relationship in which they were victims of gender violence, associating the possibility of working in Chile with the desire to economically sustain a decision to separate that they had taken previously ${ }^{9}$.

This feature of female agency is noted in another item. The decision to migrate was predominantly taken by the women: $69 \%$ decided to do so alone, while $20 \%$ indicated that it was a family arrangement, and $8 \%$ said it was their partner's decision. Indeed, most of them concreted the act in solitude: $60 \%$ migrated to Chile alone, while $26 \%$ traveled with a direct relative, and $14 \%$ did so with one or more friends.

\section{Family Responsibilities}

In Arica, $69 \%$ of the women surveyed were mothers ${ }^{10}$. This influences many of their decisions about their mobility and their working life, because they are the main providers for their family nucleus: a role that extrapolates economic obligations, since these migrants are also the emotional, affective and decision-making references for their children and, often in many cases for their mothers, sisters and brothers too. It is worth noting that $49 \%$ of the surveyed Peruvian women's children were younger than 14 years old, being economically dependent on their mothers (18\% were aged 5 or less and $31 \%$ were between 6 and 14 years old). But $36 \%$ of the children declared, who were between 15 and 24 years old, were also economically dependent on the women. Only $15 \%$ of the sons and daughters declared by the surveyed women were over 25 years old and economically self-sufficient. Although $71 \%$ of these children were born in Peru - which means 29\% are Chilean children - almost half of them $(49 \%)$ live in Chile. The remaining $51 \%$ live in Peru ${ }^{11}$.

\footnotetext{
${ }^{9}$ In most cases, women had formed free unions in Peru: the $48 \%$ that declared being "single" includes the large group of women who had separated from a "de facto" relationship.

${ }^{10}$ In total, $49 \%$ were mothers of one or two children. $11 \%$ of them had 3 children and $7 \%$ had 4 . Only one woman reported having more than five children.

${ }^{11}$ More than half of the respondents $(55 \%)$ think that it is better to educate the minor children in Chile. In contrast, $57 \%$ said that, in the case of teenagers, it was preferable to have them in Peru. Many of them stated that the education of young people in Chile is deficient in moral terms (lax in relation to the respect to the elders, an aspect that is fundamental to them).
} 
On the other hand, $44 \%$ of the children do not live with their mother, but are cared for by family members (usually the maternal grandmother, or an aunt). But the above varies according to the child's age, since the women prefer to have their children close to them when they are very young and share their upbringing with other female figures when they consider them more grownup. Among all the women surveyed, we counted 32 children under the age of 15 , of whom 28 lived with their mothers and 3 with their grandmothers. Of the 12 cases of children under 15 living in Peru, eight migrants confirmed their desire to bring them to Chile, noting that they did not do so for lack of financial resources, because the father disagrees or because the salaries obtained in Chile render more when they are sent to Peru (enabling the children to have a higher standard of living). These situations and obligations endorse the process of stress and burden on the women, and the difficulties they face in trying to reconcile their productive life on the Chilean side, with their reproductive responsibilities in Peru.

The women's role as economic providers is verified by the fact that $63 \%$ of them affirmed sending economic remittances to Peru: $26 \%$ did it monthly, $18 \%$ every week, and $7 \%$ between 2 and 5 times a year. $4 \%$ of them stated that they did it once a year, 3\% each time they go to Peru (which, in some cases, could be twice a week, given their border circularity between Arica and Tacna). Finally, 3\% did so whenever the children or relatives asked for it.

This information corroborates our analysis of the centrality of the role of the mothers and the female importance in the social reproduction of cross-border families. As we stated previously, women do not claim to migrate centrally for family reasons, but rather for issues related to better living conditions (whether related to their insertion in the labor/productive market, or to the freedom to come and go). However, the uses given to the economic resources derived from the female labor in Chile are centrally linked to the productive and reproductive burden of these women in their families ${ }^{12}$.

\footnotetext{
${ }^{12}$ When we asked the women that declared sending remittances about the primary uses of these resources, $62 \%$ indicated "family support", 21\% mentioned their children's "educational expenses", 5\% talked about "family debt payments", and 5\% mentioned "family health expenses". When we inquired about the secondary uses of these remittances, $30 \%$ of women continue to indicate "family support" and another $30 \%$ refers to "family health expenses", while $20 \%$ refer to "educational expenses", and 13\% speak of the "construction and/or improvement of the family home". Regarding the tertiary uses of resources, the family dimension is confirmed again: $23 \%$ indicated "family health expenses", $19 \%$ indicated "construction and/or improvement of family housing" and $12 \%$ mentioned the "educational expenses of the children".
} 


\section{Precarious Labor and Family Violence}

Migration is not the only experience that appeared in our survey as closely linked to the Peruvian women's family background: informality at work and gender violence are also important.

Regarding the first of these aspects, labor insertion, $45 \%$ of the women stated that their father worked "for himself or informally" in Peru (without a contract or stable labor ties), while $40 \%$ said that their mothers did the same. In the case of fathers, work in "temporary jobs" is the second most mentioned occupational situation (32\%), unlike the maternal case, in which the second most important activity is "unpaid family work" (39\%). While 17\% mentioned that their fathers enjoyed formal work (with a contract), only $6 \%$ declared that their mothers had achieved this. Thus, gender patterns are very important in the constitution of work experience in the family: most of the mothers experienced unstable labor realities (without a contract) or without remuneration (taking care of domestic reproduction or working in the family's agricultural tasks with no payment).

The mothers' realities seem to constitute gendered patterns that impact on the labor insertion of Peruvian migrant women on both sides of the border. In Arica, $92 \%$ of the Peruvian women respondents work in some activity, and $87 \%$ receive some salary (only $5 \%$ indicated to work without remuneration in the family home or business). Many of them (67\%) confirmed working more than 45 hours per week (the maximum established by the Chilean State), while $20 \%$ told us they usually worked between 31 and 45 hours each week. Around $47 \%$ of them received a fixed monthly salary for their work, $42 \%$ worked informally (e.g. without a contract, for themselves, as street vendors), clearly reproducing their mothers' and fathers' legacy.

Regarding work activities, trade is the main labor niche for $72 \%$ of migrants: reminding us of the historical role played by women in the Atacama territories located between the coast and the Andean Plateau. The second main occupational niche identified by the respondents is domestic work, which was carried out by $14 \%$ of them.

The predominance of informal work within the Peruvian women makes for precarious legal status in Chile, since the possession of a formal employment contract is a determining factor when applying for a residence permit in the country. Despite their informal work, $40 \%$ of respondents in Arica have the Permanent Residence Permit. Many of them affirmed that they obtained it thanks to President Michelle Bachelet's campaigns of migratory regularization carried out in her first government term (2006-2010). Over 27\% mentioned 
living and working in Chile with a Tourist Visa, which, at least formally, prohibits them from working.

Another important factor in relation to the transborder life of these women is linked to the generalization of the violence experienced in Peru and Chile: 22\% of Peruvian women reported having suffered (or suffering) assaults and violence by men in their family of origin ( 5 of these 22 cases involved rape). Meanwhile, $16 \%$ reported having suffered or suffering violence perpetrated by their mother, stepmother, sisters or aunts (there was no mention of sexual abuse carried out by women of the family). Thus, the survey showed $38 \%$ of women reporting experiences of violence in their family in Peru. The figure is higher than the Chilean national average for this type of violence, which, in turn also has very high levels ${ }^{13}$. On the other hand, $25 \%$ said they experienced physical violence at the hands of their partners in Peru (6 of these 25 women spoke of rape), and $8 \%$ suffered violence in their current marital relationship.

We also recorded other violence linked to economic strategies of the women's primary family in Peru: $19 \%$ of the respondents reported having been given by their parents, on one or more occasions, for domestic slave-labor in childhood, being "donated" to other families as part of the establishment of a monetary exchange. Among them, 5\% were delivered by their parents once, $6 \%$ twice, and 3\% between 3 and 4 times, while 5\% were delivered 5 or more times to work in exchange for food and lodging. To understand this construction of a family trajectory of violence, it is necessary to look closely at the Peruvian women's narratives.

\footnotetext{
13 According to the latest National Survey of Victimization of Domestic Violence and Sexual Offenses conducted in Chile (in 2012), 31.9\% of women aged 15-65 (the same age group of our sample) reported having suffered some kind of violence by a family member in their life (Sernam, 2013). In the region of Arica y Parinacota, $44.5 \%$ of the women surveyed (among whom migrants are also counted) denounced experiencing some type of violence in the current year (the national average for the item is 42.4\%) (Sernam 2013:19). In this border region, $77.5 \%$ of women reported having suffered violence in their lives (Sernam, 2013:19). This data corroborates that the attacks on women are naturalized and occur daily in Arica y Parinacota. But this does not detract from our qualitative and quantitative appreciation that this violence tends to be more intense in the case of migrant women.
} 


\section{A stranger in home h $^{14}$}

In the Borderlands/you are the battleground/where enemies are kin to each other;/you are at home, a stranger,/the border disputes have been settled/the volley of shots have scattered the truce/you are wounded, lost in action/dead, fighting back;/[...]/To survive the Borderlands/you must live sin fronteras/be a crossroads.

(Anzaldúa, 1987:194-195).

Although there is little consensus regarding the relation between alcohol abuse and gender violence in social research worldwide, many studies carried out in Latin American contexts has showed that "cohabitation, female-dominant decision making, and partner alcohol are positively associated with domestic violence" (Dallan; Forsten, 2006:19). International and cross-cultural studies agree with these assertive (Buvinic et al, 1999), particularly in case studies developed in Peru (Orosco et al, 2003; Villanueva, 2012).

The above comes to light in our case study. We get a clearer picture of the $38 \%$ of migrants surveyed who claim to have experienced violence in their nuclear families of origin as we go deeper into these women's life-histories gathered as qualitative interviews. Although characterizing these stories of violence through a limited number of determining factors would be a reductionism, we would like to provide here a general identification of the elements linked to these experiences that appear more frequently in the women's narratives.

First, the women tell us about family environments structured around male violence, in which abuse against female figures - grandmothers, mothers, aunts, sisters and themselves are generalized and naturalized. In the reports of abuse, a wide range of violence is narrated, going from undermining female opinion to systematic physical aggression:

My mother worked most of the day, [she used to] leave the house at seven [am] and arrived home at seven at night. My father, while working in the hospital, also used to leave at seven $[\mathrm{am}]$ and arrived at three in the afternoon. But sometimes, he would not appear until five, seven at night, eight at night. He would start to drink, come home drunk, and he was a bad drunk. He would grab all of us, from the eldest to the youngest and he would hit us with his belt. It began with our mother and ended with all the children. That was my father. Until the day he died, he was always the same (Heydi, 53 years).

In that sense... What can I tell you? It was a very complex [childhood]. Today I can say this calmly. But, for me, at that age, it was very difficult. I did not understand many things that happened in my home. Because my parents were always fighting. They were always separating and then getting back together. So, as I was the eldest daughter, and as I used to see all of that, sometimes I, suddenly, I would stand in between them, so they would not fight. Then, I got the slaps (Lolis, 39 years).

\footnotetext{
${ }^{14}$ Following the ethical commitments of research established by the Chilean National Commission of Scientific and Technological Research (CONICYT), the statements of our interviewees will be related to initials or pseudonyms (they decided which to use). With the women who chose pseudonyms, we performed an exercise in which they imagined an alternative identity and told us the story of this identity. All the interviews cited were recorded in Spanish and transcribed in that language.
} 
But these abuses were also exercised against underage sons, shaping the aggressions in relation to the patriarchal control of the entire family nucleus:

\begin{abstract}
Since he was a boy [her younger brother], he stayed with my mother ${ }^{15}$. And my dad would control him by hitting him. He would send him off to shepherd in this way [through beating]. Then my brother, he followed in his footsteps, he worked in the same way, on the farm. He [the brother] would hit all the women [her and her sisters] (Rafaela, 33 years).
\end{abstract}

As men grow up, they inherit this wicked kind of male power, which is passed down from man to man in the family, as in an exercise of assignment of a blood right: a succession chain between the father and his male descendents. In some cases, this masculine power is also assumed by other men, especially their mothers' partners (when the women have separated from their daughter's progenitor):

\begin{abstract}
Until one day the man who lived with my mother appeared, and I was standing at the door. And, really, I took ... I was so afraid, because that man hit my mom, hit us, and he also raped me. And I was already terrified. And my sister developed a stutter, from so many blows. Because, because, we saw that he was killing my mom. We, as far as we could, defended ourselves. [We were] little girls, and he, with a single swipe, like that, would knock us far away. Yes, he was abusive, he was a man, he was strong, and so on (La Guerrera, 54 years).
\end{abstract}

The figure of the mother's partner implies more danger for the women in a family context. Many interviewees told us about the recurrent sexual abuse at the hands of stepfathers:

He used to touch me and so on. And I used to get away. And so, it was. Then, he would get drunk and say: 'Now, lie down on the bed. Come now'. And I would say: "No, Dad! No, no". And I used to escape. That is, at that time, I was sharper and I distracted him, so as not to let him get away with his desires. That was how time passed. I would stay calm and he would tell me things, he would touch me. But he would not take off my clothes, to do what he wanted. No! I did not let him go any further. Until one day I found out that he was doing the same thing to my sister, and that hurt me. It hurt me because I said: 'No, not with my sister, I know what she is like. She is not one to complain. She is quiet; she does not know how to say no'. She is, she's like afraid, something like that. That's when I said: 'No! We have to do something'. I said: “No, no, no!” (La Guerrera, 54 years).

Second, as is clear from the accounts so far, this masculine violence is strongly associated with alcoholism. It is also related to certain sexual and recreational liberties in public spaces that are not granted to our interviewees' mothers:

\footnotetext{
${ }^{15}$ Rafaela is referring here to the fact that her only brother, unlike her many sisters and her, was not donated by their father for slave-work. We will discuss this practice later in this section.
} 


\begin{abstract}
My dad always got waylaid. There was a lot, a lot, a lot of abuse. From my dad towards my mom. My dad used to beat my mom terribly. At the end, at the end of the month, when he should have received his salary, my mother would call the company: 'No, your husband has already received his payment'. And suddenly, my dad disappeared for one week. The women already knew my father. Every time my dad got paid, the women were already there. Then he disappeared. And after that, he would come home without any money and, he would complain to my mother, demanding: "where's my dinner?" (Daiana, 35 years).
\end{abstract}

Third, the institutionalization of these patriarchal patterns and of masculine violence generates an environment from which our interviewees' mothers have not been able to free themselves. Migrants tell us, in countless stories, that their own mothers reproduced these practices towards them, and towards their minor children. Violently entangled in these relationships, the mothers used to reproduce some of the conditions of their own subordination. The data on the violence imparted by women to other women in their families is an indication of the perverse structure of this process:

My mom hit me hard. It was demeaning. [...]. Because my mom even stepped on my neck. That is, an endless number of things. I don't do that to my children. I don't do that in my home. It was something ... It was atrocious, and I am only telling you the less serious things (Daiana, 35 years).

Fourthly, these violent patterns are replicated in the masculine control over women's bodies, which is doubly linked to the female workforce and their reproductive capacity. Both will be assumed as elements to be controlled by men. In relation to the reproductive capacity, the men's loss of control over the sexuality of the female members of their family legitimizes the violence they inflicted on them and their partners. It perpetuates the notion that women can only exercise their sexuality if they are formally transferred from their father's control to the control of another man (usually chosen by the fathers or with their consent). The cases of Lolis and Daiana, who had fallen pregnant before marriage, and while they were still living in their parents' house, exemplify this control over the women's bodies:

I didn't know what to say. I guess I hadn't even finished telling him, when my dad started kicking me. He grabbed me with a whip and hit me...I can't even begin to tell you what he did to me! And that is how it was. And then, he didn't say a word to me, he didn't even ask who the father was, what he was like. Nothing. He crossed the street, to where the boy was [the father of her baby], to speak to him. And he also hit him and he did the same to him (Lolis, 39 years).

Of course, I was five to six [months pregnant]. You couldn't tell, I didn't have a belly. From there on my mother began to cry: 'Tell me the truth, tell me the truth!' She was about to hit me. Even knowing that I was grownup, my mother never stopped hitting me. I approached her in tears. I said: 'yes, Mom. I'm in the family way'. (...). My dad came and said: 'Oh, she has to leave. She has to go. Let her go. I'm not here to be dishonored'. Once and again his beliefs: 'Daughters must have a 
husband to have a child. She has to leave. She might be my daughter, but I am going to kill her', my dad said. He wanted to kick me out. My brothers wanted to hit me (Daiana, 35 years).

Regarding the control of women's bodies as a productive force, the narratives detail, among other examples, the practice of exchanging young women to work in the homes or properties of their fathers' relatives (or friends), as being used to enforce the reciprocal systems of alliances of communitarian kinship and network. Through these donations, the girls are forced to work as slaves: without any other remuneration than their daily food and lodging, and are exposed to significant patterns of verbal, psychological, and physical abuse on the part of those that received them (who also acquire the right to pass them on to other people, without their father's or their own consent). These patterns of violence caused emotional confusion for the girls. Despite the cruelty that characterizes these agreements, they are socially labeled as a "compadrazgo" relationship (one similar to that of a godparent), and therefore, the girls are forced to treat those to whom they are donated with respect, calling them "godmother" and "godfather":

She told me [the 'godmother']: 'What do you call this? Is it beef stew?' And she threw everything in my face. She threw it in my face, then she said: 'What is this meat? What have you done?' (...) 'She doesn't know how to cook, she doesn't know how to sew'. And then she hit me. And so, I learned, bit by bit whilst being hit (...). My dad never came to pick me up. No school or anything. So, in Arequipa, I grew up, I went to work in other houses as well. And again, my godmother's mom took me to her house, and there I was. And there she was a bit calmer. But when I was little, they made me suffer. And that was my life. And after there, I worked in a house, then in another, and then little by little, I grew up (Soledad, 48 years).

At 14 [years-old] I had to escape because the torture was too much. I was totally locked up; I could only go out to take the kids to school, then straight back to cooking. They said to me: 'What took you so long? Look how long you've been!' And 'bang': they hit me. There were neighbors who warned me, when I managed to escape, I ran away three times. The second time, they said to me: 'Ah, you are going to die' (Fabiana, unknown age).

Mothers did not always agree with giving up their daughters, but they had no right to manifest that, as our interviewees indicate to us. The fathers, in turn, justified or overlooked the abuses inflicted by the "godfathers" and "godmothers" to guarantee the economic or social support provided by the compadrazgo:

My mom didn't agree, but she had to, because it was my dad who sent me, a girl couldn't do anything. I went here and then there again, my godmother never sent me to school. There I discovered that the cows they supposedly had, weren't theirs. They were taking care of them for someone else. So, all that work they should have done, they gave it to me. And when I insisted that I had to go to school, they would tell me no, that I had to bring the alfalfa, to milk the cows. Then, if I got back early, 
I could go. When I had done all that work, I was late, I was behind schedule, only then would I go to school. But it was too late; they wouldn't let me in (Rafaela, 33 years).

In addition, as Rafaela also relates, another symbolic ambiguity was instilled in this process, since, in paternal discourses, women had to accept and acknowledge that their cession to other families was intrinsically good, as was the violence to which they were exposed:

He [her father] always said when he sent us to the other people, that it wasn't because we lacked food. No! According to him, it was for our own good, to learn as grownups to value things (Rafaela, 33 years).

Finally, there are nuances in these processes that should not be neglected. It turns out that our interviewees' mothers are not tacit reproducers of this violence: they also embody, just like their daughters, strategies of resistance and solidarity that are intertwined by mutual recognition. They share a feminine form of consciousness and are to some degree aware of the dimensions of the abuse to which they are exposed in the family environment. Maternity, a powerful element of mutual identification among those women, is one of the structuring axes of this feminine resistance. Daiana's case fully illustrates this:

\footnotetext{
As she was in my belly [referring to her baby], my mother, did defend me at that time. She defended me. I spent all my pregnancy with my mother. I cried a lot. There came a time when I would punch myself in the belly. And I didn't understand. I would ask: 'But why? Why?' Then, I would say: 'no, it's not her [her baby girl] fault' (Daiana, 35 years).
}

When her mother recognizes Daiana's pregnancy she offers her support against the violence of Daiana's father and brothers. Her mom stopped hitting her and came to her aid. This recognition of Daiana's feminine condition generates a cycle: Daiana herself, who at first exerts violence against her baby - punching her pregnant stomach in desperation-, realizes that what she carries inside her is a girl and extends her the same recognition that she received from the person who would become the baby's grandmother. However, this important moment of self-recognition among women does not restrain Daiana's attitude of self-rejection for not having fulfilled her father's patriarchal principles - "beliefs", as she calls them - about women's sexuality. The feminine solidarity is constantly crisscrossed by patriarchal contradictions, but despite that, it articulates strong forms of resistance. 


\section{Final remarks}

Although the empirical information treated in the text gives rise to several analytical outcomes, we will focus on three aspects that allow us to link the empirical findings of our study with the historical and theoretical debates developed previous sections of the article.

First, the study corroborates the constitution of a contradiction between the illegal nature of gender-based violence on both sides of the border and the social legitimacy it enjoys. The progressive national implementation of legislation to protect women in Peru and Chile does not disrupt the social legitimacy acquired by these abuses in Tacna and Arica. The laws derived from a debate carried out at the political centers of the countries do not have immediate impact at the border areas. The latter reminds us, once again, about the dialectical and asymmetrical character of the composition of these frontier spaces in the national scenarios. On the other hand, on both sides of the border, the types of violence that are considered legitimate are particularized. In Chile, violence towards Peruvian women is legitimate in the public space: it is linked to labor exploitation, and to racist and misogynist treatment from local Chileans. In Peru, aggressions are legitimized in intrafamily spaces. Echoing the debates of Cardin (2012) and Grimson (2000), we observed that women play with border crossings to overcome the aggressions on both side of the borders. This debate opens new interests of research regarding the asymmetries of legal regulations among the border countries and their impact on women's experiences, trajectories and mobilities. Thus, we suggest the need to deepening on a new case study on these issues. The latter would also include the research on the difference between diverse kinds of violence: direct, physical violence as well as labour exploitation. Second, this sexist violence constitutes a "masculine domination" (Bourdieu, 1998:17), as defined in the theoretical section of this article. Transversal forms of masculine domination are reproduced in the families of origin of the Peruvian women we interviewed: the desire to dominate and possess marks social relations and the constitution of conflicts in the social field. Simultaneously, they structure patterns of power that grant this privilege to the masculine gender.

Hence the coherence between what we observed in the women's families of origin and Anzaldúa's poem about the female condition on the border (which opened the previous section): women are strangers in their own house. They constitute an element to be dispossessed at many levels: bodily, psychologically, and emotionally (Segato, 2003; 2013). A male sovereignty is exercised on their body that is analogous to the Nation-state's modern sovereignty over its alleged territory (Segato, 2003:20). This plunder is ambiguously 
personified in the figures of the migrant women's fathers, brothers, mothers, godfathers and godmothers. We could then extrapolate the verses of Anzaldúa: enemies are not only "related to each other", they are related to the women themselves.

Third, the women's accounts elucidate that male abuses are challenged by forms of resistance that they observe and learn from their own mothers. These forms of resistance are embodied by women's strategies of mutual recognition and solidarity. Therefore, they constitute a particular feminine agency: they allow women to become aware of these processes of subordination and violence, and to desire to stop their reproduction (Daiana highlights that she was especially concerned not to beat her children the way her mother had beaten her). However, these strategies are embedded by the contradiction between the reproduction and the rupture of the patriarchal order due to, among other things, the inability of the women themselves to break radically away from the cycles of violence of which they are part (which have macro-symbolic, social and economic dimensions against which it is difficult to impose resistance).

This circumstance generates relational pattern in which women enter and leave relationships where the boundaries between violence and family ties are blurred. This ambiguity becomes a structure of understanding applicable to other forms of relationship with violence: in the workplace, in love relationships, in the relationships with men in general, and with the States' institutions.

We could say that the dialectic between particularisms and universalisms of the national formation in these spaces pushes people to incorporate liminal forms that constitute their actions, identities and experiences. But this will be even more intense in the case of women, and perhaps more incident, between Peruvian and Bolivian women on the Chilean side of the Andean TBA, since they constitute the most subaltern element of the patriarchy of nations in this territory.

Women's relational ability pushes them toward an agency that, at least partially, has the power to break some of the structures of patriarchal domination. The learning of this feminine resistance from their own mothers stimulates in the women dispositions of action: it pushes them towards a desire to break away from these processes of domination (e.g. to obtain economic self-sufficiency, which they get by going to work on the Chilean side of the frontier). Resisting their bodies (very often through motherhood) women break and, at the same time, reproduce contradictorily the patriarchal principles of their domination.

Consequently, even though the illegal character of gender-based violence does not disrupt the social legitimacy acquired by these abuses on both sides of the Chilean-Peruvian 
border, the agency of the migrant women persists in challenging this complex array of forces. However, the dialectic between wanting to and effectively being able to break away from the conditions of violence makes these women come and go, situationally, between processes of subordination and processes of empowerment. This condition of entry and exit, rather than a passing stage, conditions their way of life.

These women embody their feminine condition as a border crossing. They "are a cross", alluding once more to Anzaldúa's poem. Their border identity is due not only to the territory where they currently live, in which many of them were not even born $(81 \%$, as we explained, are not originally from the border city of Tacna). They manage to survive in this space because the dialectic of entry and exit of the violence that frames their early lives allows them to incorporate liminal capacities of resistance and accommodation.

In their life trajectories, the Peruvian migrant women actively re-signify the limits between the lawful and the illicit; specifically, through the (re)production and rupture of this historically legitimate character that is attributed to gender violence in these spaces, balancing situationally in this intricate state of affairs. There is thus a double dialectical contradiction: the tension between social legitimacy and illegality; and between agency and subordination. The experience of violence is a form of social and identity liminality that women wish to alter from a very feminine standing point.

\section{References}

AMILHAT-SZARY, Anne-Laure (2007), "Are Borders More Easily Crossed Today? The Paradox of Contemporary Trans-Border Mobility in the Andes". Geopolitics, v. 12, n. 1, pp. 1-18 [Consut. 1909-2019]. Available at https://www.tandfonline.com/doi/abs/10.1080/14650040601031065

ANZALDÚA, Gloria (1987), Borderlands-La Frontera. The New Mestiza. San Francisco, Aunt Lute Books.

ARAÚJO, Kathya, LEGUA María C.; OSSANDÓN, Loreto (2002), Migrantes andinas en Chile. El caso de la migración peruana. Santiago, Fundación Instituto de la Mujer.

BECKMAN, Ericka (2009), "The creolization of imperial reason: Chilean state racism in the war of the Pacific". Journal of Latin American Cultural Studies, v. 18, n. 1, pp.73-90 [Consult. 19-092019]. Available at https://www.tandfonline.com/doi/abs/10.1080/13569320902819786?journalCode=cjla20

BOURDIEU, Pierre (1998), La dominación masculina. Barcelona, Anagrama.

BRENNA, Jorge E. (2011), "La mitología fronteriza: Turner y la modernidad". Estudios Fronterizos, v. 12, n. 24, pp. 9-34 [Consult. 19-09-2019].

Available at http://www.scielo.org.mx/pdf/estfro/v12n24/v12n24a1.pdf 
BRYCESON, Deborah; VUORELA, Ulla (2002), "Transnational Families in the 21st Century", In: D. Bryceson; U. Vourela (Eds.), The Transnational Family. Oxford, Berg Publishers, pp. 3-30.

BUTLER, Judith (2011), "Replantear el universal: la hegemonía y los límites del formalismo", in J. Butler; E. Laclau; S. Žižek (Eds.), Contingencia, hegemonía, universalidad: diálogos contemporáneos de la izquierda. Buenos Aires, Fondo de Cultura Económica, pp. 19-50.

BUVINIC, Mayra; MORRISON, Andrew; SHIFTER, Michel (1999), Violence in Latin America and the Caribbean: a framework for action. Washington, Inter-American Development Bank [Consult. 19-09-2019]. Available at http://biblioteca.cejamericas.org/handle/2015/688

CARDIN, Eric (2012), "Trabalho e práticas de contrabando na fronteira do Brasil com o Paraguai". Revista Geopolíticas, v. 3, n. 2, pp. 207-234 [Consult. 19-09-2019]. Available at https://core.ac.uk/download/pdf/38816066.pdf

CARRASCO, Celina; VEJA, Patricia (2011), Una aproximación a las condiciones de trabajo en la Gran Minería de Altura. Santiago, Dirección de Trabajo del Gobierno de Chile.

CRENSHAW, Kimbely (1991), "Mapping the margins: Intersectionality, identity politics, and violence against women of color". Stanford Law Review, n. 6, pp.1241-1299 [Consult. 19-092019]. Available at

https://heinonline.org/HOL/LandingPage?handle=hein.journals/stflr43\&div=52\&id=\&page=

DIRECCIÓN PARA LA COMUNIDAD DE CHILENOS EN EL EXTERIOR [DICOEX] (2005), Chilenos en el exterior. Donde viven, cuántos son y qué hacen los chilenos en el exterior. Santiago, Ministerio de Relaciones Exteriores de Chile.

DILLEHAY, Tom; NÚÑEZ, Lautaro (1988), "Camelids, caravans, and complex societies in the South-Central Andes", in N. J. Saunderns; O. Montmollin (Eds), Recent studies in pre-Columbian archaeology. Oxford, BAR International Series, pp. 603-634.

DORE, Elizabeth (2000), "One step forward, two steps back. Gender and The State in Latin American in the Long Nineteenth Century", in

Hidden histories of gender and the state in Latin America, E. Dore; Molyneuz (Eds.). Duham, Duke University Press, pp. 3-32.

ENCUESTA DE CARACTERIZACIÓN SOCIOECONÓMICA NACIONAL [CASEN] (2013). Síntesis de resultados. Santiago, Ministerio de Desarrollo Social.

FLAKE, Dallan; FORSTE, Renata (2006), "Fighting families: family characteristics associated with domestic violence in five Latin American countries". Journal of Family Violence, v. 21, n. 1, pp. 19 [Consult. 29-09-2019]. Available at https://link.springer.com/article/10.1007/s10896-005-9002-2

GLUCKMAN, Max (2006), "Ethnographic Data in British Social Anthropology”, In: T. M. S. Evens; D. Handelman (Eds.). The Manchester School. Practice and Ethnographic Praxis in Anthropology. Nueva York, Berghahn Books, pp. 13-22.

GONZÁLEZ, Sergio (2006), Arica y la triple frontera, Integración y Conflicto entre Bolivia, Perú y Chile. Iquique, Aríbalo Ediciones.

GONZÁLEZ, Sergio (2009), "El Norte Grande de Chile y sus dos Triple-Fronteras: Andina (Perú, Bolivia y Chile) y Circumpuneña (Bolivia, Argentina y Chile)". Cuadernos interculturales, v. 7, $\mathrm{n}$. 13, pp. 27-42 [Consult. 19-09-2019].

Available at https://www.redalyc.org/pdf/552/55212234003.pdf 
GRAMSCI, Antonio (1984), Notas sobre Maquiavelo, sobre la política y el Estado moderno. Buenos Aires, Nueva Visión.

GRIMSON, Alejandro (2000), “¿Fronteras políticas versus fronteras culturales?”, in A. Grimson (Ed.). Fronteras, Naciones e Identidades. Buenos Aires, CICCUS, pp. 9-40.

GRIMSON, Alejandro (2003). "Disputas sobre las Fronteras", in S. Michaelsen; D. Johnson (Eds.). Teoría de la frontera: los límites de la política cultural. Barcelona, Gedisa, pp. 13-23.

GRIMSON, Alejandro; GUIZARDI, Menara (2015), "Matices y límites del trasnacionalismo: los contextos de la migración en Chile", in M. Guizardi (Ed.), Las fronteras del Transnacionalismo. Límites y desbordes de la experiencia migrante en el centro y norte de Chile. Santiago, Ocho Libros, pp. 13-36.

GUIZARDI, Menara; GARCÉS, Alejandro (2012), "Mujeres peruanas en las regiones del Norte de Chile: Apuntes preliminares para la investigación". Revista de Estudios Atacameños, n. 44, pp. 534 [Consult. 19-09-2019]. Available at https://scielo.conicyt.cl/scielo.php?pid=S0718$10432012000200002 \&$ script=sci_arttext\&tlng=e

GUIZARDI, Menara; GARCÉS, Alejandro (2013), "Circuitos migrantes. Itinerarios y formación de redes migratorias entre Perú, Bolivia, Chile y Argentina en el norte grande chileno". Papeles de Población, v. 19, n. 78, pp. 65-110 [Consult. 19-09-2019]. Available at http://www.scielo.org.mx/scielo.php?pid=S1405-74252013000400005\&script=sci_arttext.

GUIZARDI, Menara; GARCÉS, Alejandro (2014), "Estudios de caso de la migración peruana 'en Chile': un análisis crítico de las distorsiones de representación y representatividad en los recortes espaciales". Revista de Geografía Norte Grande, n. 58, pp. 223-240 [Consult. 19-09-2019]. Available at https://scielo.conicyt.cl/scielo.php?pid=S0718-34022014000200012\&script=sci_arttext\&tlng=en

GUIZARDI, Menara; HEREDIA, Orlando; MUÑOZ, Arlene; DÁVILA, Grecia; VALDEBENITO, Felipe (2014), "Experiencia migrante y apropiaciones espaciales: una etnografía visual en las inmediaciones del Terminal Internacional de Arica (Chile)". Revista de Estudios Sociales, n. 48, pp. 166-175 [Consult. 19-09-2019]. Available at https://journals.openedition.org/revestudsoc/8336.

GUIZARDI, Menara; VALDEBENITO, Felipe; LÓPEZ, Eleonora; NAZAL, Esteban (2015), "Condensaciones en el espacio hiperfronterizo: Apropiaciones migrantes en la frontera Norte de Chile", in M. Guizardi (Ed.), Las fronteras del Transnacionalismo. Límites y desbordes de la experiencia migrante en el centro y norte de Chile. Santiago, Ocho Libros, pp. 224-257.

HONDAGNEU-SOTELO, Pierrette; AVILA, Ernestine (1997), "I'm Here, but I'm There. The Meanings of Latina Transnational Motherhood". Gender and Society, v. 11, n. 5, pp. 548-571 [Consult. 19-09-2019].

Available at https://journals.sagepub.com/doi/abs/10.1177/089124397011005003

HYDÉN, Margareta (2005), "I must have been an idiot to let it go on: Agency and positioning in battered women's narratives of leaving". Feminism \& Psychology, v. 15, n. 2, pp. 169-188 [Consult. 19-09-2019].

Available at https://journals.sagepub.com/doi/abs/10.1177/0959353505051725

JENSEN, María F. (2009), "Inmigrantes en Chile: la exclusión vista desde la política migratoria chilena", in E. Bologna (Ed.), Temáticas migratorias actuales en América Latina: remesas, políticas y emigración. Rio de Janeiro, ALAP, pp. 105-130. 
KEARNEY, Michael (1991), "Borders and Boundaries of State and Self at the End of Empire". Journal of Historical Sociology v. 4, n. 1, pp. 52-74 [Consult. 19-09-2019]. Available at https://onlinelibrary.wiley.com/doi/abs/10.1111/j.1467-6443.1991.tb00116.x

LAMAS, Marta (2000), "Usos, dificultades y posibilidades de la categoría género". Papeles de Población n. 21, pp. 148-178 [Consult. 19-09-2019]. Available at https://www.redalyc.org/pdf/112/11202105.pdf

LARRAÍN, Paz (2000), "Mujeres tras las huellas de los soldados". Revista de Historia (Santiago) n. 33, pp. 227-261 [Consult. 19-09-2019].

Available at https://scielo.conicyt.cl/scielo.php?script=sci_abstract\&pid=S0717$71942000003300005 \& \operatorname{lng}=$ es\&nrm=iso

Larson, Brooke (1995), "Andean Communities, Political Cultures, and Markets: The Changing Contours of a Field", in L. Brooke; O. Harris; E. Tandeter (Eds.), Ethnicity, markets, and migration in the Andes: at the crossroads of history and anthropology. Durham, Duke University Press, pp. 5-54.

LEVITT, Peggy; GLICK-SCHILLER, Nina (2004), "Perspectivas transnacionales sobre la migración: conceptualizar la simultaneidad”. Migración y Desarrollo, n. 3, pp. 60-91 [Consult. 19-09-2019]. Available at https://www.redalyc.org/pdf/660/66000305.pdf

MANGAN, Jane (2005), Trading Roles: Gender, Ethnicity, and the Urban Economy in Colonial Potosí. Durham, Duke University Press.

MARCUS, George (1995), "Ethnography in/of the World System: The Emergence of Multi-Sited Ethnography". Annual Review of Anthropology, n. 24, pp. 95-117 [Consult. 19-09-2019]. Available at https://www.annualreviews.org/doi/abs/10.1146/annurev.an.24.100195.000523

MARTÍNEZ, Jorge (2003), El mapa migratorio de América Latina y El Caribe, las mujeres y el género. Santiago, CELADE-CEPAL.

McEVOY, Carmen (2011), Guerreros y civilizadores. Política, sociedad y cultura en Chile durante la Guerra del Pacífico. Santiago, Ediciones UDP.

MILLS, Mary Beth (2003), "Gender and Inequality in the Global Labor Force". Annual Review of Anthropology, n. 32, pp. 41-62 [Consult. 19-09-2019]. Available at https://www.annualreviews.org/doi/abs/10.1146/annurev.anthro.32.061002.093107

MONÁRREZ, Julia E.; TABUENCA, María S. (2013), "Presentación”, in J. E. Monárrez; M. S. Tabuenca (Eds.), Bordeando la violencia contra las mujeres en la frontera norte de México. San Antonio del Mar, El Colegio de la Frontera Norte, pp. 3-19.

NAVARRETE, Bernardo (2007), "La quinta oleada migratoria de peruanos a Chile: los residentes legales". Revista Enfoques, v. 7, pp. 173-195 [Consult. 19-09-2019]. Available at https://www.redalyc.org/pdf/960/96000707.pdf.

NÚÑEZ, Lorena; HOLPER, Dany (2005), "En el Perú, nadie se muere de hambre: pérdida de peso y prácticas de alimentación entre trabajadoras domésticas peruanas", in U. Berg; K. Paerregaard (Eds.), El quinto suyo. Transnacionalidad y formación diaspórica en la migración peruana. Lima, Instituto de Estudios Peruanos, pp. 291-313.

OROSCO, Távora; SAMAMÉ, Tula; ZELAYA, Ceiso; ARIAS, María L.; OSTOLAZA, Nohemí (2003), Detección de violencia basada en género en tres servicios de atención de salud 
reproductiva. Revista Peruana de Ginecología y Obstetricia, v. 49, n. 1, pp. 31-38 [Consult. 19-092019]. Available at http://www.spog.org.pe/web/revista/index.php/RPGO/article/view/459/426

PERKMANN, Markus; SUM, Ngai-Ling (2002), Globalization, regionalization and cross-border regions: scales, discourses and governance. London, Palgrave Macmillan.

PÉREZ, Carlos; Menara GUIZARDI; VICUÑA, José T.; ROJAS, Tomás (2015), "Del contexto fronterizo y migratorio", in J. T. Vicuña; T. Rojas (Eds.), Migración internacional en Arica y Parinacota: Panoramas y tendencias de una región fronteriza. Santiago, Editorial de la Universidad Alberto Hurtado, pp. 49-70.

PICKERING, Sharon (2011), Women, Borders, and Violence. Current Issues in Asylum, Forced Migration, and Trafficking. New York, Springer.

POBLETE, Roberto (2006), "Educación intercultural: teorías, políticas y prácticas. La migración peruana en el Chile de hoy. Nuevos escenarios y desafíos para la integración”, PHD Dissertation (PhD on Socio-cultural Anthropology), Autonomous University of Barcelona.

PODESTÁ, Juan (2011), "Regiones fronterizas y flujos culturales: La peruanidad en una región chilena". UNIVERSUM, v. 1, n. 26, pp. 123-137 [Consult. 19-09-2019]. Available at https://scielo.conicyt.cl/scielo.php?pid=S0718-23762011000100008\&script=sci_arttext

ROJAS, Nicolás; SILVA, Claudia (2016), La migración en Chile: breve reporte y caracterización. Madrid, OBIMID.

ROSENBLITT, Jaime (2013), Centralidad geográfica, marginalidad política: La región Tacna-Arica y su comercio, 1778-1841. Santiago, Centro de Investigaciones Barros Arana.

SATER, William (2007), Andean tragedy: fighting the war of the Pacific, 1879-1884. Lincoln, University of Nebraska Press.

SCHIAPPACASSE, Paulina (2008), "Segregación espacial y nichos étnicos de los migrantes internacionales en el Área Metropolitana de Santiago". Revista de Geografía Norte Grande, n. 39, pp. 21-38 [Consult. 19-09-2019]. Available at https://scielo.conicyt.cl/scielo.php?pid=S071834022008000100003\&script=sci_arttext

SEGATO, Rita L. (2003), Las estructuras elementales de la violencia. Ensayos sobre género entre la antropología, psicionálisis y los derechos humanos. Buenos Aires, Prometeo.

SEGATO, Rita L. (2013), La escritura en el cuerpo de las mujeres asesinadas en Ciudad Juárez. Territorio, soberanía y crímenes de Segundo Estado. Buenos Aires, Tinta de Limón Editores.

SEMPAT, Carlos (1995), "Exchange in the Ethnic Territories between 1530 and 1567: The Visitas of Huanuco and Chucuito", in L. Brooke; O. Harris; E. Tandeter (Eds.), Ethnicity, markets, and migration in the Andes: at the crossroads of history and anthropology. Durham, Duke University Press, pp. 101-134.

SERVICIO NACIONAL DE LA MUJER [SERNAM] (2013), Encuesta Nacional de Victimización por Violencia Intrafamiliar y Delitos Sexuales, 2012. Santiago, Ministerio del Interior y Seguridad Pública de Chile.

SPIVAK, Gayatri (1998), “¿Puede hablar el sujeto subalterno?”. Orbis Tertius, v. 3, n. 6, pp. 175-235 [Consult. 19-09-2019]. Available at https://www.orbistertius.unlp.edu.ar/article/view/OTv03n06t01 
STEFONI, Carolina (2005), "Inmigrantes Transnacionales. La formación de comunidades y la transformación en ciudadanos", in U. Berg; K. Paerregaard (Eds.), El quinto suyo. Transnacionalidad y formación diaspórica en la migración peruana. Lima, Instituto de Estudios Peruanos, pp. 261-289.

STERN, Steve (1995), "The Variety and Ambiguity of Native Andean Intervention in European Colonial Markets", in L. Brooke; O. Harris; E. Tandeter (Eds.), Ethnicity, markets, and migration in the Andes: at the crossroads of history and anthropology. Durham, Duke University Press, pp. 73-100.

SUM, Ngai-Ling (2003), "Rethinking Globalisation: Re-articulating the Spatial Scale and Temporal Horizons of Trans-Border Spaces", in N. Brenner; B. Jessop; M. Jones; G. Macleod (Eds.), State/Space: A Reader. Oxford, Blackwell Publishing, pp. 208-224.

TAPIA, Marcela (2012), "Frontera y migración en el norte de a partir del análisis de los censos población: Siglos XIX-XXI". Revista de Geografía Norte Grande, v. 53, pp. 177-198 [Consult. 1909-2019]. Available at https://scielo.conicyt.cl/scielo.php?pid=S0718-34022012000300011\&script=sci_arttext

TAPIA, Marcela (2015), "Frontera, movilidad y circulación reciente de peruanos y bolivianos en el norte de Chile". Estudios atacameños n. 50, pp. 195-213 [Consult. 19-09-2019]. Available at https://scielo.conicyt.cl/scielo.php?pid=S0718-10432015000100010\&script=sci_arttext\&tlng=en

TAPIA, Marcela; RAMOS, Romina (2013), "Mujeres migrantes fronterizas en Tarapacá a principio del siglo XXI. El cruce de las fronteras y las redes de apoyo". Polis, v. 12, n. 35, pp. 229-257 [Consult. 19-09-2019]. Available at https://journals.openedition.org/polis/9321

TUNG, Tiffiny (2008), "Life on the move: bioarchaeological contributions to the study of migration and diaspora communities in the Andes", in H. Silverman; W. Isbell (Eds.), The Handbook of South American Archaeology. New York, Springer, pp. 671-680.

UNITED NATIONS [UN] (2015), World Urbanization Prospects. New York, United Nations' Department of Economic and Social Affairs.

VALDEBENITO, Felipe; GUIZARDI, Menara (2014), "Las fronteras de la modernidad. El espacio Tacnoariqueño y la nacionalización del Norte Grande chileno (1883-1929)". Revista de Estudos Ibero-Americanos, v. 40, n. 2, pp. 277-303 [Consult. 19-09-2019]. Available at https://www.redalyc.org/pdf/1346/134635319006.pdf

VICUÑA, José T.; GUIZARDI, Menara; PÉREZ, Carlos; ROJAS, Tomás (2015), "Características Económicas y sociodemográficas de la Región de Arica y Parinacota", in J. T. Vicuña; T. Rojas, Migración internacional en Arica y Parinacota: Panoramas y tendencias de una región fronteriza. Santiago, Ediciones Universidad Alberto Hurtado, pp. 37-48.

VILLANUEVA, Sabina (2013), "Violencia familiar asociado al consumo de sustancias psicoactivas en hombres que ejercen violencia". Avances en Psicología, v. 21, n. 1, pp. 35-46 [Consult. 19-092019]. Available at http://revistas.unife.edu.pe/index.php/avancesenpsicologia/article/view/304.

VITALE, Luis (2011), Interpretación marxista de la historia de Chile. Santiago, LOM. 


\section{Resumen}

El artículo discute las estrategias articuladas por las mujeres peruanas de la zona fronteriza entre Chile y Perú para enfrentar las legitimaciones históricas de la violencia de género en este territorio. En Perú, sus trayectorias están marcadas por violaciones, explotación laboral, secuestro y trabajo esclavo. En Chile, otras violencias y discriminaciones (laborales, documentales, agresiones machistas) persisten, siendo apoyadas en un discurso sobre la inferioridad étnico-nacional de las peruanas. Se observa, así, una tensión entre legitimidad social e ilegalidad jurídica, y entre agencia y subordinación en lo que concierne a la violencia de género. A partir de datos etnográficos, definiremos esta tensión como un proceso que (re)inscribe, en las trayectorias vitales de las mujeres, formas dispares de marginación y cruce fronterizo.

Palabras clave: Violencia, género, migración femenina, frontera Chile-Perú.

\section{Resumo}

$\mathrm{O}$ artigo discute as estratégias articuladas pelas mulheres peruanas na zona fronteiriça entre Chile e Peru para enfrentar a legitimidade histórica da violência de gênero neste território. No Peru, suas trajetórias são marcadas por estupro, exploração laboral, sequestro e trabalho escravo. No Chile, outras formas de violência e discriminação (laborais, documentais, agressões machistas) persistem e são apoiadas por um discurso sobre a inferioridade étnica e nacional das mulheres peruanas. Assim, existe uma tensão entre legitimidade social e ilegalidade legal, e entre agência e subordinação em relação à violência de gênero. A partir de dados etnográficos, definiremos esta tensão como um processo que (re)inscreve, nas trajetórias vitais das mulheres, formas díspares de marginalização e de passagem de fronteiras.

Palavras-chave: Violência, gênero, migração feminina, fronteira Chile-Peru. 